\title{
Crossrail project to deliver London's Elizabeth line: the parliamentary bill
} process

Simon Bennett BEng, FCILT, MCIPR, GMICE

Head of Learning Legacy, Crossrail Limited, London, UK

The Crossrail programme to deliver the Elizabeth line east-west railway across London, UK, was authorised by the Crossrail Act 2008. It was the culmination of 6 years of planning and development work by an organisation called Cross London Rail Links, which was created for the purpose as a joint venture between the Strategic Rail Authority (succeeded by the Department for Transport) and Transport for London. This paper explains the process of obtaining authorisation for the $\mathbf{f 1 4 . 8}$ billion project through a hybrid parliamentary bill process.

\section{Introduction}

The UK's Strategic Rail Authority (SRA) and Transport for London (TfL) formed Cross London Rail Links (CLRL) Limited in 2001 to define and develop the design of the Crossrail project to deliver a new east-west railway across London, UK (Bennett, 2017). Following 3 years of route option selection, consultation and design development, approval was finally given in late 2014 to deposit a hybrid public/private parliamentary bill to authorise the $£ 14.8$ billion project.

The Department for Transport (DfT) became closely involved in the process as the project group moved towards introduction of the bill. The Secretary of State for Transport was the promoter of the bill while CLRL remained the organisation with the principal resources and the necessary specialist expertise to support it.

Douglas Oakervee, past president of the Institution of Civil Engineers, was appointed as executive chairman of CLRL to lead the project. The company was also reorganised into bill and development functions, with Keith Berryman appointed managing director of the former.

Critical functions were brought together in the bill directorate, such as the liaison with the DfT bill team, the team of counsel that would represent the promoter and parliamentary agents, environment, traffic and property specialists and bill-related engineering.
Some CLRL functions were divided, such as the consultation and bill management teams being moved from the public affairs department into a new government liaison department. Headed by Simon Knight, seconded from the DfT, this led the preparation for and management of the parliamentary select committee process.

The DfT appointed a group of officials to oversee negotiations, established a suite of governance meetings to manage the bill and petition handling and response processes, and appointed an advisory group of professionals with previous hybrid bill experience.

\section{Bill scheme and information round}

In late 2004, the scheme was revised to terminate the southeastern branch at Abbey Wood (see Figure 1). Combined with extending overhead electrification from Custom House to Abbey Wood, this change obviated the need to provide both dual-voltage trains and a location to switch current.

It also avoided issues with limited capacity through Dartford station to run additional trains to Gravesend. Nevertheless, the intention remained to allow for future extension and in due course a safeguarding direction was made for a route through Gravesend, with Crossrail trains able to reverse to the east of Hoo Junction.

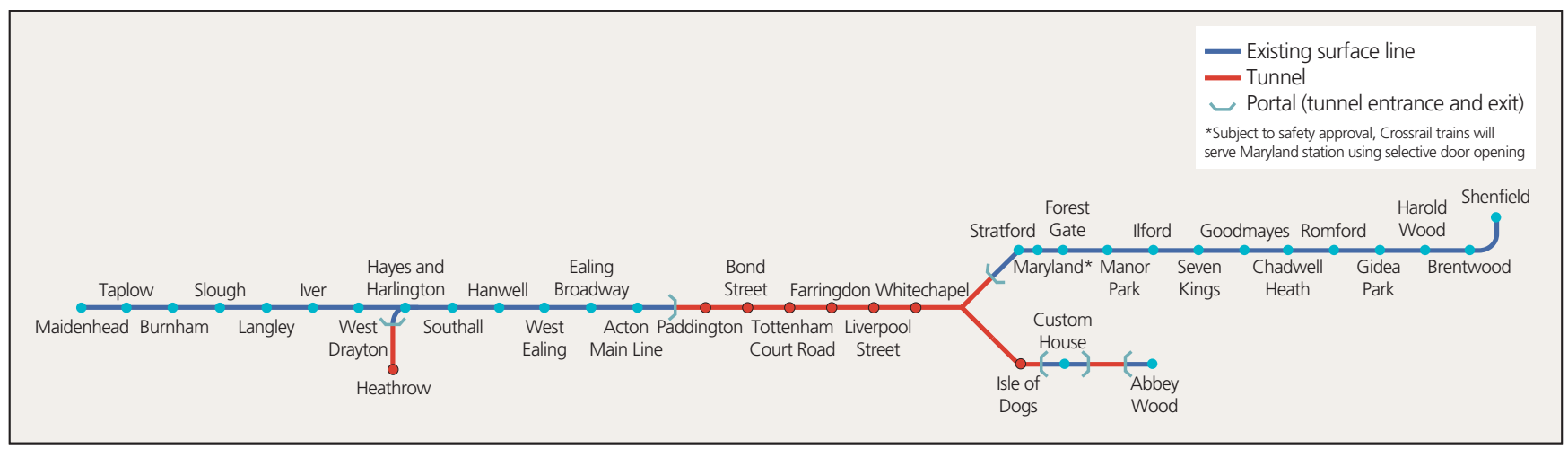

Figure 1. Crossrail route as presented in Crossrail bill 
A third round of information centres and consultation meetings was held in January 2005 to ensure that those who might petition the bill were aware of all the changes and the final scheme extent. Having had DfT review and endorsement of the information papers (Crossrail, 2006) by this stage was helpful, as these were now available to be quoted and provided as a standard (common) response to potential petitioners with similar concerns.

The process was successful in alleviating many concerns and is believed to have diminished the number and force of remaining petitions.

\section{The bill process}

The Crossrail bill was deposited on 5 February 2005 (DfT, 2005a). This was late for the introduction of a hybrid bill, as parliamentary rules stipulate that such bills should be introduced by 23 November at the start of the parliamentary year. The bill was not ready to be introduced in November 2004, so dispensation had to be sought from the House of Commons authorities to deposit outside that timetable.

For various reasons including the intervening general election, second reading of the bill was on 19 July 2005. This was easily passed thanks to the cross-party support for the scheme. Parliament then rose, so the petitioning period did not end until after the house returned after the summer recess.

Three hundred and sixty-five petitions were received and as soon as they started to arrive, work began to review and understand the implications of each, and negotiation began with the petitioners to address and alleviate concerns. This process involved the CLRL petitions team plus specialists within CLRL as well as additional consultants, DfT officials and lawyers from the promoter's parliamentary agents.

The process used was a development of that used for the Channel Tunnel rail link (CTRL) bill. Each petition was analysed and the individual issues raised were given codes. Quite often, because many petitioners used the same parliamentary agents, issues were similar across petitions.

Standard petition responses were created for a large proportion of these coded issues and those responses were checked and signed off by the petition management group, being sure to understand the implications of any concession and the extent it might be claimed elsewhere. A petition response document was then crafted for each petition, using the standard responses, where relevant (with specific details and additions in some cases), and with bespoke responses to those issues that were unique to the petition.

Each issue was presented on a new page, with the text of the petition reproduced at the top so that it could be clearly seen what the response related to. An example page is shown in Figure 2. These response documents in effect became the promoter's opening position in any negotiation that followed.

It was slightly different to the CTRL process, in which the response documents were produced after negotiations. However, despite some reservations that there might be complaints that the responses came before a negotiation, nearly all petitioners and their agents seemed to accept that this process allowed both sides to focus quickly and concentrate on the most important issues of a negotiation, or if that failed to resolve the issue, an appearance before the select committee was required.

Very few of the petitions were from individuals, companies or organisations who might be considered not to have a qualifying interest in the scheme (known as locus standi, a legal term translating as 'a place to stand'). It is open to the promoter to challenge a petitioner's locus standi but, as these challenges must be heard first, and would probably involve the select committee hearing at least part of the petitioner's case anyway, it was decided not to make any challenges as this might have given a negative impression of the promoter's willingness to listen and reconsider.

As is always the case, the promoter's parliamentary agent was instrumental in the process of agreeing the order of petitioners' appearances in select committee, with a dedicated individual being identified at the outset to do this full time. This attempted to group similar cases together, broadly in a geographical order, to try to achieve consensus for the committee and perhaps telescope the sitting times.

Similar petitioners, for example property owners, might also be grouped. However, this was not allowed to result in the promoter controlling the process; the representative from the agent was scrupulous not to allow the promoter to inconvenience petitioners.

Because of the extended period before the House of Commons select committee was assembled, it was necessary for the promoter to make amendments to the powers being sought as a result of technical improvements, some from the petitioning process.

A supplementary environmental statement (SES) was published in May 2005 (DfT, 2005b) and in January 2006 it was necessary to introduce an amendment to provisions and a second accompanying SES (DfT, 2006a). The main subject of

\begin{tabular}{|c|c|c|c|}
\hline \multicolumn{4}{|c|}{ HOUSE OF COMMONS SELECT COMMITTEE } \\
\hline \multicolumn{4}{|c|}{ GROSSRAIL BILL } \\
\hline \multicolumn{3}{|c|}{ PROMOTER'S RESPONSE TO PETITION OF: } & Corporation of London \\
\hline \multicolumn{3}{|c|}{ PETITION NUMBER: } & 26 \\
\hline \multicolumn{3}{|c|}{ PETITION PARAGRAPH: } & 48 \\
\hline \multicolumn{2}{|c|}{ ISSUE RAISED: } & Salt store & \\
\hline \multicolumn{2}{|c|}{$\begin{array}{l}\text { PETITION } \\
\text { PARAGRAPH: }\end{array}$} & \multicolumn{2}{|c|}{$\begin{array}{l}\text { Your petitioners submit that the nominated undertaker should be } \\
\text { required either to facilitate the continued use by your petitioners of } \\
\text { the premises as a store for road salt, to enable them to fulfil their } \\
\text { statutory obligations, or to provide an acceptable alternative } \\
\text { location for the store during the duration of the works. }\end{array}$} \\
\hline \multicolumn{4}{|c|}{ PROMOTER'S RESPONSE: } \\
\hline 1. & \multicolumn{3}{|c|}{$\begin{array}{l}\text { Assuming that the General Market area has not been redeveloped (please see } \\
\text { the Promoter's response to petition paragraph } 47 \text { ) and that the salt store has not } \\
\text { already moved, the Promoter will require the nominated undertaker to provide } \\
\text { access to the salt store for the petitioner's use on terms having regard to existing } \\
\text { arrangements, via the existing NCP ramp, which is located just off the junction of } \\
\text { Farringdon Road and West Smithfield. This ramp will be shared by both } \\
\text { Crossrail construction traffic needing to access the Cardinal House worksite } \\
\text { through the basement of General Market and the petitioners vehicles. }\end{array}$} \\
\hline 2. & \multicolumn{3}{|c|}{$\begin{array}{l}\text { In the event that the General Market has been redeveloped prior to } \\
\text { commencement of Crossrail construction, and that the salt store has not been } \\
\text { relocated either before or as part of the redevelopment, the petitioner will need to } \\
\text { agree with the developer alternative arrangements for access, and the grant of } \\
\text { any necessary new rights from the developer for the purpose. The Promoter is } \\
\text { willing to discuss how the alternative access to be agreed by the petitioner with } \\
\text { the developer can be provided in a way which is also consistent with access } \\
\text { arrangements required for Crossrail. }\end{array}$} \\
\hline
\end{tabular}

Figure 2. Extract from a petition response document 


\section{To assist the select committee to assimilate the significant amount of information presented to them, CLRL procured a bespoke audiovisual system}

the amendment to provisions was to revise the location of the proposed ticket hall at Whitechapel station from Court Street to Fulbourne Street and the SESs dealt with impacts from utility diversions which it had become clear were necessary, and provided further information about the consideration of options for a shaft at Hanbury Street.

A second amendment to provisions (DfT, 2006b) was deposited in May 2006 and was mainly concerned with the acquisition of additional land in an industrial estate in Bow in order to avoid the relocation of a travellers' site.

\section{House of Commons select committee hearings}

The House of Commons select committee first public hearing was on 17 January 2006 and the process of hearing petitions progressed rapidly. Several meetings were held with the select committee clerks to agree the process. To assist the select committee to assimilate the significant amount of information that was to be presented to them, CLRL procured a bespoke audiovisual system - called the parliamentary support system (PaSS) - to enable evidence to be displayed on screens in the select committee room (Figure 3).

A portable version was required as the first few sittings of the select committee were held in Portcullis House before transferring to committee room 5 in the Palace of Westminster (Figure 4) for the vast majority of the hearings, where the house had allowed the promoter to make a more permanent installation. Using PaSS allowed the promoter to be helpful in developing

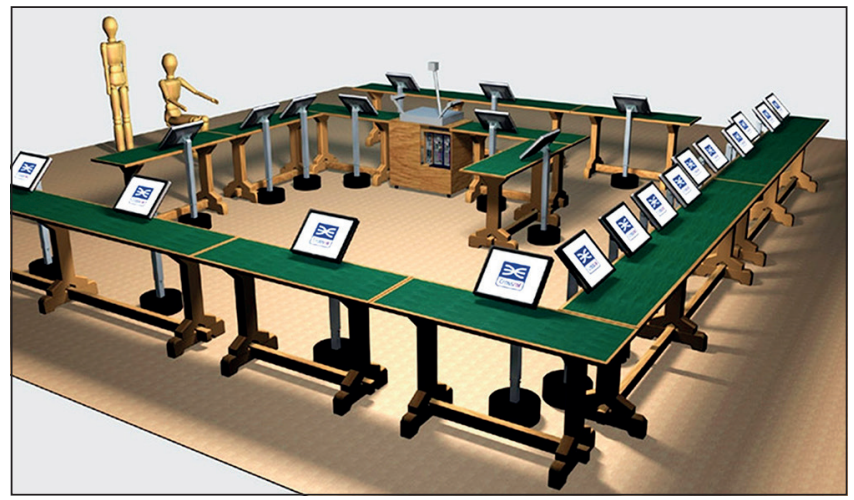

Figure 3. Three-dimensional render of parliamentary support system hardware in committee room a discipline of producing promoter's evidential documents and adding them to the PaSS database in advance. They were therefore also available in a timely manner for petitioners for their use.

The system had a rostrum camera so that late-entry items from either the promoter or petitioners could be displayed in real time for ingestion later. Given the development of technology which has occurred since the Crossrail bill was presented, a future project could provide a more sophisticated system with the necessary safeguards to ensure the veracity and acceptability of the material being presented in evidence.

Preparing for the defence of the Crossrail scheme before the select committee required careful management to reduce the time required. It included negotiations with petitioners to reduce the need to appear. Conferences with the promoter's counsel were then held at which they were briefed and in turn asked searching questions of CLRL and DfT representatives and expert witnesses to enable them to lay out the promoter's position and to avoid significant challenge.

To assist their and petitioners' understanding, the House of Commons select committee required counsel for the promoter to make a brief statement at the beginning of each case to explain the issues of contention. Counsel quickly demonstrated their ability to do so in an unbiased way so that many petitioners saw the benefit of this approach. Both parties were able to call witnesses to give evidence and then to be cross-examined. It became clear that consistency and a rapport with the members of the select committee and their clerk were beneficial and expedited the process considerably.

However, it meant that the burden of being witness for the promoter fell disproportionately on one or two individuals with a wide and deep grasp of the facts about the project, the ability to form an excellent relationship with counsel and above all the ability to explain issues clearly for the select committee and petitioners. Identifying individuals with that particular skill set will be a difficult but very important task for future promoters.

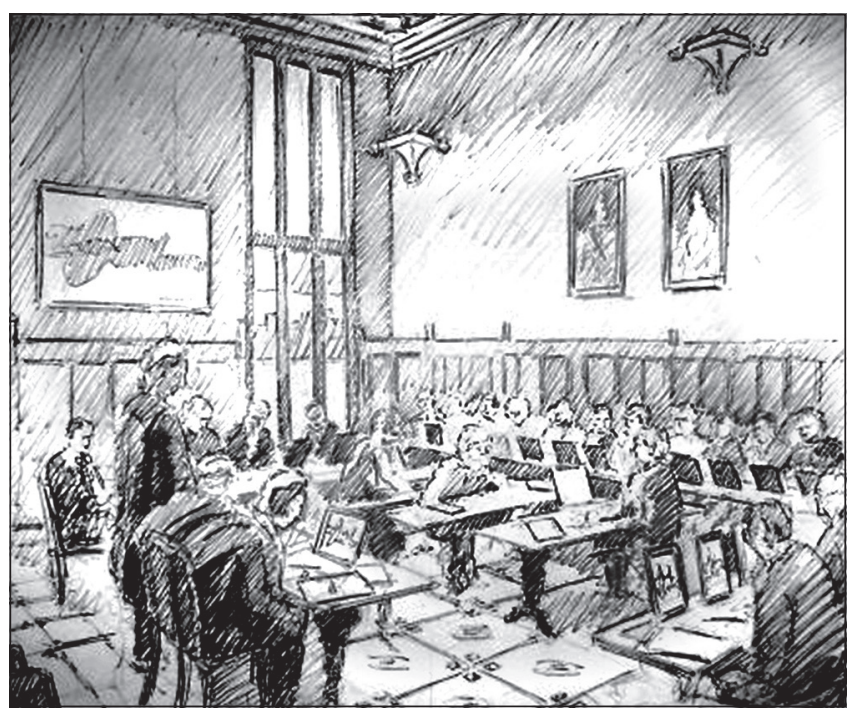

Figure 4. Committee room 5 
During the first few months of hearings, several issues arose which required further work to resolve. The select committee issued a set of interim decisions at the end of the parliamentary session in July 2006, which enabled the promoter's teams to use the summer recess to work on responses to these and the related negotiations with petitioners. This additional work resulted in a third amendment to provisions, which included applications for powers for the following

- an additional ticket hall at Broadgate (Liverpool Street) in response to petitions from the Corporation of London and British Land

- an additional entrance at Bond Street station (City of Westminster), to be delivered by London Underground to cater for anticipated passenger numbers

- works to provide lifts giving step-free access at an additional four stations on the Shenfield branch

- relocating an existing freight depot at Old Oak Common (London Borough of Hammersmith and Fulham) to provide space for the main Crossrail rolling stock depot to be located there, rather than at Romford (London Borough of Havering).

Other changes were made to the scheme, which did not require new works or powers as they were operational details not requiring powers or where there were no significant changes in environmental impact, as follows

- a revised tunnelling strategy, removing the need to launch tunnel boring machines at Hanbury Street (London Borough of Tower Hamlets) and the proposed excavated material tunnel from there to a site adjacent to the Great Eastern main line at Pedley Street, Shoreditch (also Tower Hamlets)

- acceptance of operating trains with selective door opening at less busy stations, enabling the deletion of some platform lengthening works at Hanwell (London Borough of Ealing), and for the scheme to serve Maryland (London Borough of Newham).

The select committee also required the promoter to provide a station at Woolwich (House of Commons Select Committee, 2006). As this would have increased the project cost, it took longer to develop a proposal that would deliver a station without increasing the overall cost of the scheme.

It was done by redesigning the alignment between the Thames tunnel and the Plumstead portal. This section had initially been designed with a shallow ruling gradient which the SRA had mandated to allow freight trains to run. Since the possibility of operating freight no longer existed as a result of other parts of the freight route having been closed to make way for Olympic transport infrastructure, the redesign allowed a steeper gradient up from beneath the Thames and hence a cheaper cut-and-cover station to be designed.

The redesign in turn allowed CLRL to enter into negotiations with the London Borough of Greenwich and the developers of the former Woolwich Arsenal site, Berkeley Homes, for Berkeley to construct a station box in return for intensifying development, with a view to a further agreement to fit the station out. This was detailed in a final amendment to provisions in May 2007 (DfT, 2007).
Overall the House of Commons select committee received 457 petitions, of which 205 were heard over 84 sitting days between 18 January 2006 and 10 July 2007. The scheme presented to the next stage of the process had been significantly improved.

\section{Undertakings and assurances}

Many commitments were made to petitioners to address their concerns during the parliamentary process. A register of undertakings and assurances was established to record these and ensure they would be able to be enforced when the project was constructed. This listed the assurances which had been made by the promoter's counsel in parliament and incorporated those contained in the information papers that had the status of commitments.

The detailed agreements made between the transport secretary and petitioners, in which the details were confidential, were included as a summary entry. The register was sent to beneficiaries for their comments before it was finalised. The House of Commons select committee expressed a view that it was not easy for a petitioner to identify which commitments applied to them and the level of comfort they gave.

A future project ought to be able to take advantage of information technology advances to create a register that is much easier to access, search and understand. Inevitably each of the commitments had a cost but these were considered to be within the risk provision of the cost estimate and were never part of any negotiation.

\section{House of Lords select committee hearings}

A total of 113 petitions were received against the bill in the House of Lords. These were principally from petitioners who had received second house undertakings in the House of Commons that their particular issues could be heard later if not addressed through informal negotiation with the promoter in the meantime.

The House of Lords select committee first sat on 19 February 2008 and 45 petitioners made an appearance (40\% of the total). During the House of Lords select committee hearings the remaining significant generic issues between the promoter and the local authorities were settled. These were the ground-borne noise criteria for the construction and operational railways and airborne noise criteria for fixed installations.

The House of Lords select committee sat for 29 days in the period up to 8 May 2008 (House of Lords Select Committee, 2008).

\section{Royal assent}

After the House of Lords select committee concluded its hearings, the remaining formal activities necessary to proceed to royal assent were completed. A third reading and reference back to the House of Commons for consideration of the Lords' amendments took place in quite a short time, and royal assent for the Crossrail Act 2008 was given on 22 July - close to the last day of that parliamentary session. 


\section{Promoters of future schemes should carefully consider how to present information effectively}

The nomination orders for CLRL and for London Underground in relation to their works at Bond Street and Tottenham Court Road stations were signed the following day, a vital step as London Underground was keen to begin those projects.

\section{Conclusions}

A total of 464 petitions were received regarding the Crossrail bill in the House of Commons, including 99 against the four amendments to provisions. A further 113 petitions were received in the House of Lords.

Overall, this was less than half the number lodged against the CTRL bill (rail link $109 \mathrm{~km}$ long with $25 \mathrm{~km}$ in tunnel) and demonstrated the effectiveness of the consultation and information provision to reassure potential petitioners that their issues had or would be addressed.

Some of the changes to the project which resulted from negotiations with petitioners, in particular the Liverpool Street Broadgate ticket hall, the depot at Old Oak Common rather than Romford, and inclusion of a station at Woolwich, could perhaps have been identified earlier and addressed before the bill was deposited.

Apart from the above conclusions about processes, the following conclusions can be drawn about how the project could have been even further improved, some petitions avoided, or have been better set up for the delivery phase.

- The Broadgate ticket hall being located within the road space was an option that has probably not been as cost effective as hoped because the extent of utility diversions and archaeological work was not appreciated. If petitioner concerns about ticket hall capacity had been understood and addressed during the development of the bill scheme, an alternative may have been possible.

- CLRL's policy during design development was to upgrade existing stations where projected increases in passenger numbers meant that works would be required. This meant that not all surface stations were planned to be provided with stepfree access. TfL is now carrying out works outside the Crossrail funding to ensure all stations served by Elizabeth line services are step-free from the start of the new service. Petitions and subsequent negative media coverage could have been avoided had this been recognised and funding been available during the development phase.

- In some locations, land outside that identified in the Crossrail Act 2008 was needed temporarily for construction purposes. Consent to use that land was obtained either through subsequent applications, or by agreement with landowners or local authorities. While it is necessary not to apply for land beyond that which is ultimately required, the project could have sought earlier contractor involvement to ensure the space was adequate.
As mentioned in Section 4, promoters of future schemes should carefully consider the hardware and personnel necessary to present information most effectively in committee and work with the clerks to ensure this assists all parties - promoter, petitioners and committee members.

Promoters should also, as set out in Section 5, use systems for recording and collating undertakings and assurances that make it simple to create a register and in due course to establish a commitments compliance management system during delivery.

Overall, the development and authorisation processes for Crossrail were successful and this is testament to excellent working relationships between CLRL and DfT and honest and open communication with stakeholders and petitioners.

\section{Acknowledgements}

The author is grateful for permission to document this process from the DfT and TfL. The author is also very grateful for the assistance of Keith Berryman (director of CLRL, 2001-2011), Bernard Gambrill (head of public affairs at CLRL, 2002-2006), Simon Knight (head of government liaison at CLRL, 2005-2008) and Rob Paris (head of sustainability and consents at Crossrail Limited), for providing their recollections and reviewing the author's work.

\section{References}

Bennett S (2017) Crossrail project to deliver London's Elizabeth line: from options to parliamentary bill. Proceedings of the Institution of Civil Engineers - Civil Engineering 170(6): 3-9, http://dx.doi.org/10.1680/ jcien.17.00006.

Crossrail (2006) Information Papers. See http://www.crossrail.co.uk/aboutus/crossrail-bill-supporting-documents/information-papers (accessed 16/02/2017)

Crossrail Act 2008. Chapter 18. Her Majesty's Stationery Office, London, UK. DfT (Department for Transport) (2005a) Crossrail Environmental Statement DfT, London, UK.

DfT (2005b) Crossrail Supplementary Environmental Statement. DfT, London, UK.

DfT (2006a) Crossrail Amendment to Provisions Environmental Statement. DfT, London, UK

DfT (2006b) Crossrail Amendment to Provisions 2 Environmental Statement. DfT, London, UK.

DfT (2007) Crossrail Amendment to Provisions 4 Environmental Statement. DfT, London, UK.

House of Commons Select Committee (2006) The Crossrail Bill: Woolwich Station. 1st Special Report of Session 2005-06. House of Commons, London, UK.

House of Lords Select Committee (2008) First Special Report of Session 2007-2008. Volume I: Report 112-I. House of Lords, London, UK.

How can you contribute?

If you would like to comment on this paper, please email up to 200 words to the editor at journals@ice.org.uk.

If you would like to write a paper of 2000 to 3500 words about your own

experience in this or any related area of civil engineering, the editor will be

happy to provide any help or advice you need. 